\title{
Antioxidant Properties of Hydrogen Gas Attenuates Oxidative Stress in Airway Epithelial Cells
}

\author{
In-Soo You ${ }^{1,+}{ }^{+}$Subham Sharma ${ }^{2,3,+}$, Ailyn Fadriquela ${ }^{2,4} \mathbb{D}^{\mathbb{D}}$, Johny Bajgai ${ }^{(\mathbb{D}}$, Thuy Trinh Thi ${ }^{2,3}$, \\ Md. Habibur Rahman 2,3 ${ }^{(D}$, Jaeyong Sung ${ }^{5}$, Hwang-Un Kwon ${ }^{1}$, So-Yeon Lee ${ }^{1}$, \\ Cheol-Su Kim ${ }^{2}$ (D) and Kyu-Jae Lee ${ }^{2, *}$
}

1 GOOTZ Co., Ltd., 79-6, Yuljeong-ro 247 beon-gil Yangju-si, Gyeonggi-do, Suwon 11457, Korea; igootz@naver.com (I.-S.Y.), kwon@mygootz.com (H.-U.K.), sylee@mygootz.com (S.-Y.L.)

2 Department of Environmental Medical Biology, Wonju College of Medicine, Yonsei University, Wonju, Gangwon-do, Chuncheon 26426, Korea; subhamsharma047@gmail.com (S.S.); ailynfadriquela@gmail.com (A.F.); johnybajgai@yonsei.ac.kr (J.B.); tththuy@hpmu.edu.vn (T.T.T.); pharmacisthabib@yonsei.ac.kr (M.H.R.); cs-kim@yonsei.ac.kr (C.-S.K.)

3 Department of Global Medical Science, Wonju College of Medicine, Yonsei University, Wonju, Gangwon-do, Chuncheon 26426, Korea

4 Department of Laboratory Medicine, Wonju College of Medicine, Yonsei University, Wonju, Gangwon-do, Chuncheon 26426, Korea

5 Department of Mechanical and Automotive Engineering, SeoulTech, 232, Gongreung-ro, Nowon-gu, Seoul 01811, Korea; jysung@seoultech.ac.kr

* Correspondence: medbio@yonsei.ac.kr; Tel.: +82-0337410336

+ These authors contributed equally to this work.

check for

updates

Citation: You, I.-S.; Sharma, S.; Fadriquela, A.; Bajgai, J.; Thi, T.T.; Rahman, M.H.; Sung, J.; Kwon, H.-U.; Lee, S.-Y.; Kim, C.-S.; et al. Antioxidant Properties of Hydrogen Gas Attenuates Oxidative Stress in Airway Epithelial Cells. Molecules 2021, 26, 6375. https://doi.org/ $10.3390 /$ molecules 26216375

Academic Editor: Patrick J. Farmer

Received: 24 September 2021

Accepted: 19 October 2021

Published: 21 October 2021

Publisher's Note: MDPI stays neutral with regard to jurisdictional claims in published maps and institutional affiliations.

Copyright: (C) 2021 by the authors. Licensee MDPI, Basel, Switzerland. This article is an open access article distributed under the terms and conditions of the Creative Commons Attribution (CC BY) license (https:// creativecommons.org/licenses/by/ $4.0 /)$.
Abstract: Oxidative stress plays a crucial role in the development of airway diseases. Recently, hydrogen $\left(\mathrm{H}_{2}\right)$ gas has been explored for its antioxidant properties. This study investigated the role of $\mathrm{H}_{2}$ gas in oxidative stress-induced alveolar and bronchial airway injury, where A549 and NCI-H292 cells were stimulated with hydrogen peroxide $\left(\mathrm{H}_{2} \mathrm{O}_{2}\right)$ and lipopolysaccharide (LPS) in vitro. Results show that time-dependent administration of $2 \% \mathrm{H}_{2}$ gas recovered the cells from oxidative stress. Various indicators including reactive oxygen species (ROS), nitric oxide (NO), antioxidant enzymes (catalase, glutathione peroxidase), intracellular calcium, and mitogen-activated protein kinase (MAPK) signaling pathway were examined to analyze the redox profile. The viability of A549 and NCI-H292 cells and the activity of antioxidant enzymes were reduced following induction by $\mathrm{H}_{2} \mathrm{O}_{2}$ and LPS but were later recovered using $\mathrm{H}_{2}$ gas. Additionally, the levels of oxidative stress markers, including ROS and NO, were elevated upon induction but were attenuated after treatment with $\mathrm{H}_{2}$ gas. Furthermore, $\mathrm{H}_{2}$ gas suppressed oxidative stress-induced MAPK activation and maintained calcium homeostasis. This study suggests that $\mathrm{H}_{2}$ gas can rescue airway epithelial cells from $\mathrm{H}_{2} \mathrm{O}_{2}$ and LPS-induced oxidative stress and may be a potential intervention for airway diseases.

Keywords: hydrogen gas; oxidative stress; anti-oxidant; airway epithelium; MAPK signaling

\section{Introduction}

Oxidative stress indicates an imbalance of reactive oxygen species (ROS) and antioxidants, leading to disturbance of redox homeostasis and cellular damage. Oxidative stress triggers the pathological conditions in various disorders including pulmonary diseases [1,2]. Pulmonary epithelial cells are always exposed to varieties of stress inducers, and are the main target of ROS. In airway epithelial cells, ROS and their reactions participate in the pathophysiology of several pulmonary diseases, including asthma, pulmonary fibrosis, and respiratory distress, and stimulate impairment in pulmonary function, airway remodeling, and mucus secretion [3,4]. The pulmonary epithelial cells are protected in normal conditions by high intracellular and extracellular antioxidant levels [5]. 
Airway epithelial cells including A549 cells help to transport the substances (i.e., water and electrolytes) across alveoli. In addition, A549 cells reduce surface tension, which prevents alveolar collapse during respiration [6]. Similarly, NCI-H292 cells produce mucus and proteins in the bronchi, which forms a tight barrier for immune response [7]. Studies have shown that hydrogen peroxide $\left(\mathrm{H}_{2} \mathrm{O}_{2}\right)$ and lipopolysaccharide (LPS) can be used as a strong oxidizing agent to induce oxidative stress and inflammation. With exposure to these compounds, alveolar and bronchial epithelial cell line such as A549 and NCI-H292 respond sensitively in lung injury due to oxidative stress [8-10]. One study showed that with the exposure of $\mathrm{H}_{2} \mathrm{O}_{2}$ in $\mathrm{A} 549$ cells, increased intracellular calcium $\left(\mathrm{Ca}^{2+}\right)$ concentrations lead to mitotic arrest and cell apoptosis [8]. In addition, another study revealed that LPS activates endoplasmic reticulum stress and induces apoptosis in human airway NCI-H292 cells, resulting in acute lung injury [10].

In pathological and physiological conditions, mitochondria are mainly responsible for the production of ROS [11]. About $2 \%$ of ROS are emitted out of the entire oxygen utilized by mitochondria. Abnormality in production of ROS has a deleterious effect in proper functioning and regulation of cells [12]. Similarly, reactive nitrogen species (RNS), which includes nitric oxide (NO) and its derivative the peroxynitrite (ONOO-), acts as a powerful oxidant that can damage many biological molecules [13]. Moreover, cells bring defensive systems of antioxidants into active form, which is based mainly on enzymes such as glutathione peroxidase (GPx) and catalase (CAT), to defend from damage of cells caused by ROS [14]. Furthermore, mitogen activated protein kinase (MAPK) signaling is activated in response to various cellular stimuli. Three major subfamilies of MAPK are c-Jun N-terminal kinase (JNK), extracellular signal-regulated kinase (ERK), and p38. These can promote cell death by stimulating stress, including oxidative stress; thus, inhibiting these markers can increase survival [15].

With this, there is no doubt that oxidative stress plays a vital role in the progression of airway diseases. As a result of this, research interest to assess adjuvant effects of strong antioxidant agents has been increasing recently in order to alleviate these issues. Studies have shown that molecular hydrogen $\left(\mathrm{H}_{2}\right)$ is a physiologically regulated gas molecule, which exerts antioxidant, anti-inflammatory, anti-apoptotic, and signal regulating properties $[16,17]$. Due to the fact that $\mathrm{H}_{2}$ can neutralize and convert highly active oxidants like the hydroxyl radical $\left({ }^{\bullet} \mathrm{OH}\right)$ and $\mathrm{ONOO}$ - into water, $\mathrm{H}_{2}$ is found to be beneficial for human health. $\mathrm{H}_{2}$ specifically quenches the ROS, while maintaining the metabolic oxidationreduction reaction in the cell and can easily target organelles, including mitochondria and nuclei $[16,18]$. Several studies have reported that $\mathrm{H}_{2}$ suppresses oxidative stress-induced injury in various organs, such as brain, liver, and heart with minimal toxicity [19-21]. One of the previous studies reported that $\mathrm{H}_{2}$ protected cells against $\mathrm{ROS}$ and apoptotic damage induced by irradiation of cultured epithelial cells [22].

In the present study, we attempt to explore the antioxidative effect of $\mathrm{H}_{2}$ gas in alveolar and bronchial epithelial cells using A549 and NCI-H292, where oxidative stress is induced by $\mathrm{H}_{2} \mathrm{O}_{2}$ and LPS. Moreover, this study aims to determine the effect of $\mathrm{H}_{2}$ gas on oxidative stress via MAPK signaling pathway.

\section{Materials and Methods}

\subsection{Cells and Chemicals}

A549 and NCI-H292 cells utilized in this study were obtained from the Korean Cell Line Bank (Cancer Research Institute of Seoul National University, Seoul, Korea). The cells were cultured in cell culture flasks containing Roswell Park Memorial Institute (RPMI)-1640 medium, 10\% fetal bovine serum (FBS) provided by Hyclone Laboratories (GE Healthcare Life Sciences, South Logan, UT, USA), and $1 \%$ antibiotic-antimycotic provided by Gibco (Life Technologies Corporation, NY, USA) at $37{ }^{\circ} \mathrm{C}$ with $5 \% \mathrm{CO}_{2}$ and $100 \%$ humidity. $\mathrm{H}_{2} \mathrm{O}_{2}$ (Daejeong Reagent Manufacturer, Daejung, South Korea) and LPS from Escherichia coli O111:B4 (Sigma-Aldrich, Darmstadt, Germany) were used to induce oxidative stress. 


\subsection{Experimental Design}

Oxidative stress was induced in A549 and NCI-H292 cells for $24 \mathrm{~h}$ using $\mathrm{H}_{2} \mathrm{O}_{2}$ and LPS. The cells were divided into four groups: normal control (NC; $n=3)$, induction with $\mathrm{H}_{2} \mathrm{O}_{2}$ or LPS only (Ind; $n=3$ ), induction and treatment with $\mathrm{H}_{2}$ gas for $30 \mathrm{~min}$ (Ind $+\mathrm{H}_{2}-30 ; n=3$ ), and induction and treatment with $\mathrm{H}_{2}$ gas for 60 min (Ind $+\mathrm{H}_{2}-60$; $n=3)$. In particular, A549 and NCI-H292 cells were cultured and sub-cultured in RPMI medium for a specific period of time. Both cells were isolated, counted, and seeded for $24 \mathrm{~h}$, when the confluence of cells in the culture media reached approximately $80 \%$. After the $24 \mathrm{~h}$ incubation period following the previous study by Begum et al. [23], the cells were washed, then the serum containing media was replaced with serum free media for cell synchronization and incubated with $\mathrm{H}_{2} \mathrm{O}_{2}(50 \mu \mathrm{M})$ or LPS $(50 \mu \mathrm{g} / \mathrm{mL})$, and then incubated for another $24 \mathrm{~h}$ at $37^{\circ} \mathrm{C}$ with $5 \% \mathrm{CO}_{2}$. After incubation, the cells were washed three times with $1 \times$ PBS and resuspended in RPMI medium. The relevant groups were treated with $2 \% \mathrm{H}_{2}$ gas for $30 \mathrm{~min}$ or $60 \mathrm{~min}$ after which the cells were incubated for another $24 \mathrm{~h}$. The $2 \% \mathrm{H}_{2}$ gas $(v / v \%)$ was used in this study in reference to other several studies [24-26]. The cells were then lysed and the supernatant collected. The required part of the supernatant was used for enzymatic tests whereas the rest was stored at $-80^{\circ} \mathrm{C}$ for Western blotting assays of proteins in the MAPK pathway.

\section{3. $\mathrm{H}_{2}$ Gas Treatment Procedure}

The $\mathrm{H}_{2}$ gas treatment system was designed and provided by the company (GOOTZ Co., Ltd., Gyeonggi-do, Korea). Cell culture or multi-well plates were placed inside a panaqua cube (GOOTZ Co., Ltd., Suwon, Gyeonggi-do, Korea). A voltage stabilizer along with $\mathrm{H}_{2}$ timer (Dr's Choice Co., Ltd., Tokyo, Japan) was used to fill the cube with $\mathrm{H}_{2}$ gas and measure the time. The cells were then exposed to $\mathrm{H}_{2}$ gas for either $30 \mathrm{~min}$ or 60 min. The $\mathrm{H}_{2}$ concentration in the panaqua cube was monitored using a cosmos XP3140 (Combustible gas and vapor detector), as the $\mathrm{H}_{2}$ gas was being supplied to the cube (Figure 1). After treatment with $2 \% \mathrm{H}_{2}$ gas for the specified time, the cell culture and multiwell plates were wrapped in aluminum foil. This foil aids in the long-term preservation of $\mathrm{H}_{2}$ gas and its activity in cultured cells $[23,27]$. The plates were then incubated for $24 \mathrm{~h}$ at $37^{\circ} \mathrm{C}$ in the presence of $5 \% \mathrm{CO}_{2}$ and then used for further experiments.

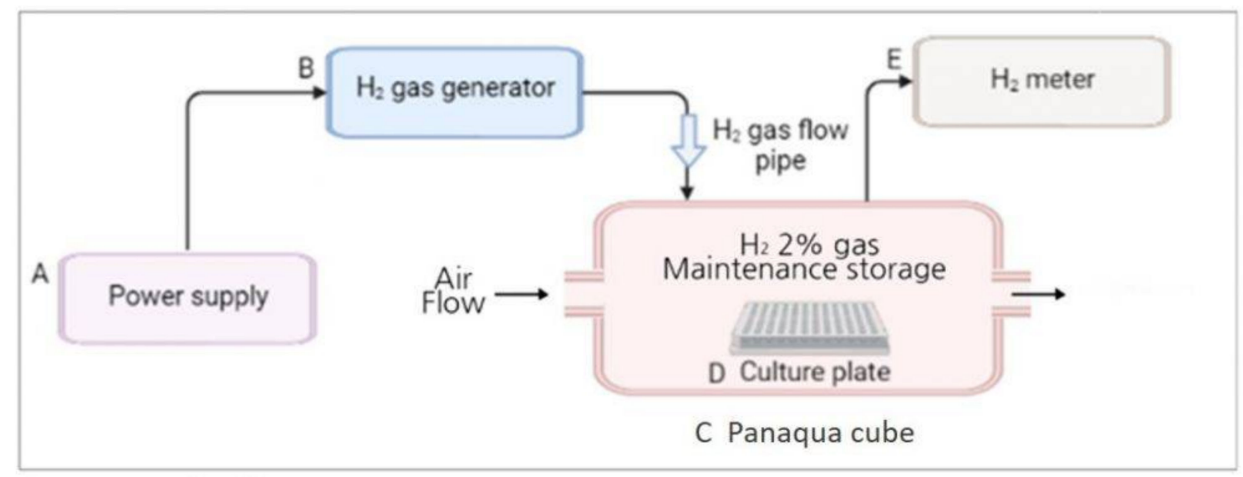

Figure 1. Overall schematic representation of the $\mathrm{H}_{2}$ gas treatment process. (A) Power supply was set at around 9 volt; (B) $\mathrm{H}_{2}$ gas generator (produces $2 \% \mathrm{H}_{2}$ gas); (C) Panaqua cube (contains culture plate for supplying $\mathrm{H}_{2}$ gas); (D) Cell culture plate; (E) $\mathrm{H}_{2}$ gas meter (measures the concentration of $\mathrm{H}_{2}$ gas in the cube).

\subsection{Cell Viability Assay}

A Cell Counting kit-8 (CCK-8) reagent from Quanti-MaxTM (Seoul, Korea) was used to analyze cell viability and proliferation following the manufacturer's instructions. In brief, A549 and NCI-H292 cells were seeded in a 96-well plate (2000 cells/well) with RPMI-1640 media and the plate was incubated at $37^{\circ} \mathrm{C}$ with $5 \% \mathrm{CO}_{2}$ for $24 \mathrm{~h}$. After treatment with $\mathrm{H}_{2} \mathrm{O}_{2}$ and LPS, the media was discarded and the cells were washed and resuspended in 
RPMI media. Cells were treated with $\mathrm{H}_{2}$ gas (2\%) for $30 \mathrm{~min}$ and $60 \mathrm{~min}$ and then incubated at $37{ }^{\circ} \mathrm{C}$ with $5 \% \mathrm{CO}_{2}$ for $24 \mathrm{~h}$. After $24 \mathrm{~h}$ of $\mathrm{H}_{2}$ treatment, $10 \mu \mathrm{L} \mathrm{CCK}-8$ solutions were added to each well and the plate incubated at $37^{\circ} \mathrm{C}$ for $2 \mathrm{~h}$. A SpectraMax ${ }^{\circledR}$ ABS Plus (Molecular Devices, San Jose, CA, USA) was used to measure the optical density (OD) at $380 \mathrm{~nm}$.

\subsection{Intracellular Measurement of Total Reactive Oxygen Species (ROS)}

The DCFDA Cellular ROS Detection Assay Kit (Abcam, Cambridge, MA, USA) was used to measure oxidative stress in A549 and NCI-H292 cells according to the manufacturer's protocol. Briefly, $10 \mu \mathrm{L}$ of the sample and $100 \mu \mathrm{L}$ of $10 \mu \mathrm{M}$ DCFH-DA were added into each well and the cells incubated for $30 \mathrm{~min}$ at $37^{\circ} \mathrm{C}$. Absorbance was measured at $488 \mathrm{~nm}$ excitation/525 $\mathrm{nm}$ emission using a DTX 880 multimode microplate reader (Beckman Counter Inc., Brea, CA, USA).

\subsection{Quantification of Nitric Oxide (NO) Production}

Griess reagent (Promega Corp., Madison, WI, USA) was used to quantify nitrite $\left(\mathrm{NO}_{2}{ }^{-}\right)$in A549 and NCI-H292 cells according to the manufacturer's instructions. To evaluate the nitrate content, $50 \mu \mathrm{L}$ of the sample was incubated at room temperature for 10 min with $50 \mu \mathrm{L}$ of sulfanilamide solution. Next, $50 \mu \mathrm{L}$ of NED solution was added and the mixture incubated for a further $10 \mathrm{~min}$ at room temperature. A SpectraMax ${ }^{\circledR}$ ABS Plus (Molecular Devices, San Jose, CA, USA) was used to measure the OD at $520 \mathrm{~nm}$.

\subsection{Assessment of Endogenous Antioxidant Enzyme Activity}

Antioxidant enzyme activity was tested in A549 and NCI-H292 cell lysate following the manufacturer's guidelines. Briefly, cells were plated in culture plates $\left(1 \times 10^{6}\right.$ cells per well), and cell lysates were collected using assay buffer. The lysates were then centrifuged at $13,000 \times g \mathrm{rpm}$ for $15 \mathrm{~min}$ at $4{ }^{\circ} \mathrm{C}$. A SpectraMax ${ }^{\circledR}$ ABS Plus (Molecular Devices, San Jose, CA, USA) was used to quantify GPx activity (Biovision Inc., Milpitas, CA, USA) and CAT activity (Biomax Co., Ltd., Seoul, Korea) in the cell lysates. GPx absorbance was measured at $340 \mathrm{~nm}$ and CAT absorbance was measured at $560 \mathrm{~nm}$.

\subsection{Detection and Quantification of Intracellular $\mathrm{Ca}^{2+}$}

Intracellular $\mathrm{Ca}^{2+}$ was measured in A549 and NCI-H292 cell lysates using a Ca ${ }^{2+}$ colorimetric assay kit (Biovision, Milpitas, CA, USA), according to the manufacturer's instructions. In brief, cells were seeded in 6-well plates for $24 \mathrm{~h}$. Following treatment, $50 \mu \mathrm{L}$ of lysate was added to each well, along with $90 \mu \mathrm{L}$ of chromogenic reagent and $60 \mu \mathrm{L}$ of $\mathrm{Ca}^{2+}$ assay buffer. Absorbance was measured at $590 \mathrm{~nm}$ using a SpectraMax®ABS Plus (Molecular Devices, San Jose, CA, USA) after $10 \mathrm{~min}$ of incubation. The results are presented in $\mathrm{mg} / \mathrm{dL}$.

\subsection{Quantification of Western Blot}

Proteins for Western blot were extracted using RIPA buffer on ice. After protein estimation and normalization, cell lysates of cell were loaded in the gel and subjected to sodium dodecyl sulfate-polyacrylamide gel electrophoresis (SDS-PAGE). The gels were then transferred to the membranes. The membranes were blocked for $2 \mathrm{~h}$ at room temperature and incubated overnight with specific primary antibodies against p-p38, p-ERK, and p-JNK (dilution: 1:1000; Cell Signaling Technology, Massachusetts, Danvers, MA, USA) to observe the proliferation, stress response, inflammation, and cell apoptosis. The samples were then incubated with anti-rabbit secondary antibody (dilution: 1:5000; Cell Signaling Technology, Danvers, MA, USA) for $2 \mathrm{~h}$ at room temperature. ECL Western Blotting Substrate was used to detect the protein bands, which was then imaged using a UVP Biospectrum 600 Imaging System (UVP, LLC, Upland, CA, USA). The intensity of the protein bands was analyzed using Image J software. 


\subsection{Statistical Analysis}

The mean \pm standard error of the mean (SEM) were used to express the data. Analysis was conducted in GraphPad Prism 5.0 software (Graph-Pad, San Diego, CA, USA). Mean values of the groups were evaluated and assessed using one-way analysis of variance (ANOVA) followed by a multiple comparison test (Tukey post hoc test). Statistical significance was defined as a difference of $p<0.05$.

\section{Results}

\subsection{Augmentation of Cell Viability Post-Treatment of A549 and NCI-H292 Cells Using $2 \% \mathrm{H}_{2}$ Gas}

To evaluate the post-treatment effect of $\mathrm{H}_{2}$ gas on airway epithelial cells, A549 and NCI$\mathrm{H} 292$ cells were treated with either $50 \mu \mathrm{M} \mathrm{H}_{2} \mathrm{O}_{2}$ or $50 \mu \mathrm{g} / \mathrm{mL}$ LPS for $24 \mathrm{~h}$ before treatment with $2 \% \mathrm{H}_{2}$ gas (Supplementary Figure $\mathrm{S} 1$ ). Our results showed that $\mathrm{H}_{2} \mathrm{O}_{2}$ induction reduced the cell viability in the A549 cell line compared with the control $(p<0.001)$, but this effect was significantly increased after treatment with $\mathrm{H}_{2}$ gas. LPS induction also decreased the cell viability $(p<0.001)$, but this was significantly improved, in a timedependent manner, after treatment with $\mathrm{H}_{2}$ gas. Similar results were observed with the NCI-H292 cells. These results show that the reduced cell viability caused by $\mathrm{H}_{2} \mathrm{O}_{2}$ and LPS induction significantly increased, in a time dependent manner, upon treatment with $\mathrm{H}_{2}$ gas (Figure 2).
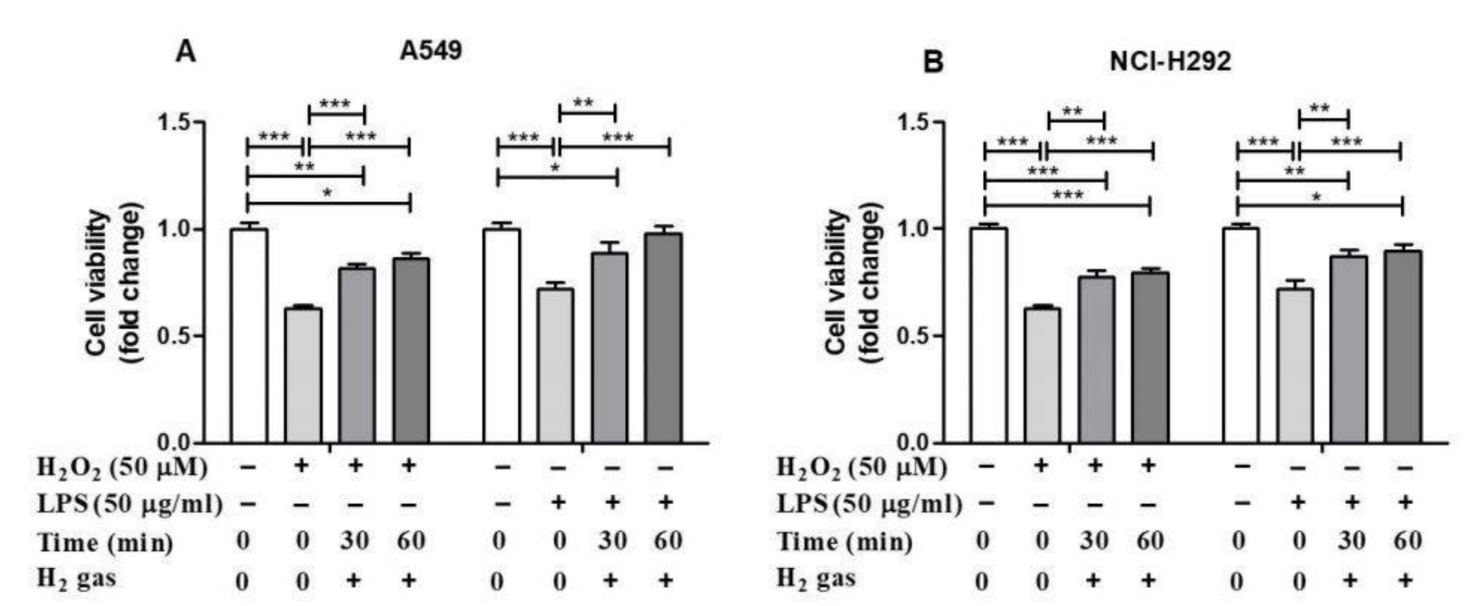

Figure 2. Effect of $2 \% \mathrm{H}_{2}$ gas on cell viability in A549 and NCI-H292 cells induced with $\mathrm{H}_{2} \mathrm{O}_{2}$ and LPS. Effect of $\mathrm{H}_{2}$ gas (30 min and 60 min post-treatment) on the viability of (A) A549 cells induced with $\mathrm{H}_{2} \mathrm{O}_{2}(50 \mu \mathrm{M})$ and LPS (50 $\left.\mu \mathrm{g} / \mathrm{mL}\right)$ and (B) NCI-H292 cells induced with $\mathrm{H}_{2} \mathrm{O}_{2}(50 \mu \mathrm{M})$ and LPS $(50 \mu \mathrm{g} / \mathrm{mL})$. Data are presented as mean \pm SEM. ${ }^{*} p<0.05$, ** $p<0.01$ and ${ }^{* * *} p<0.001$ represent significant differences based on ANOVA.

\section{2. $\mathrm{H}_{2}$ Gas Attenuated Increased ROS and NO in A549 and NCI-H292 Cells}

To demonstrate the antioxidant property of $\mathrm{H}_{2}$ gas, the levels of ROS and NO in both cell lines were determined following $\mathrm{H}_{2} \mathrm{O}_{2}$ and LPS induction. $\mathrm{H}_{2} \mathrm{O}_{2}$ and LPS induced ROS and NO production in both cell lines in comparison to untreated cells. In particular, $\mathrm{H}_{2} \mathrm{O}_{2}$ and LPS treatment significantly up regulated cellular ROS in the A549 cell line compared with the control $(p<0.001)$. The increase in ROS was reduced in a time-dependent manner after treatment with $2 \% \mathrm{H}_{2}$ gas (Figure 3A). Similarly, when ROS production in NCI-H292 cells was significantly increased by induction with $\mathrm{H}_{2} \mathrm{O}_{2}$ and LPS $(p<0.001), \mathrm{H}_{2}$ treatment significantly attenuated this increase in a time-dependent manner (Figure 3B). On the other hand, we observed a time-dependent reduction in NO levels in A549 cells following $\mathrm{H}_{2}$ gas treatment of $\mathrm{H}_{2} \mathrm{O}_{2}$ and LPS-induced cells (Figure 3C). Similarly, NO levels in NCI-H292 
cells increased significantly following $\mathrm{H}_{2} \mathrm{O}_{2}$ and LPS induction, and this increase was attenuated in a time-dependent manner by treatment with $\mathrm{H}_{2}$ (Figure 3D). This finding indicates a time-dependent decrease in ROS and NO levels following treatment with $\mathrm{H}_{2}$ gas.

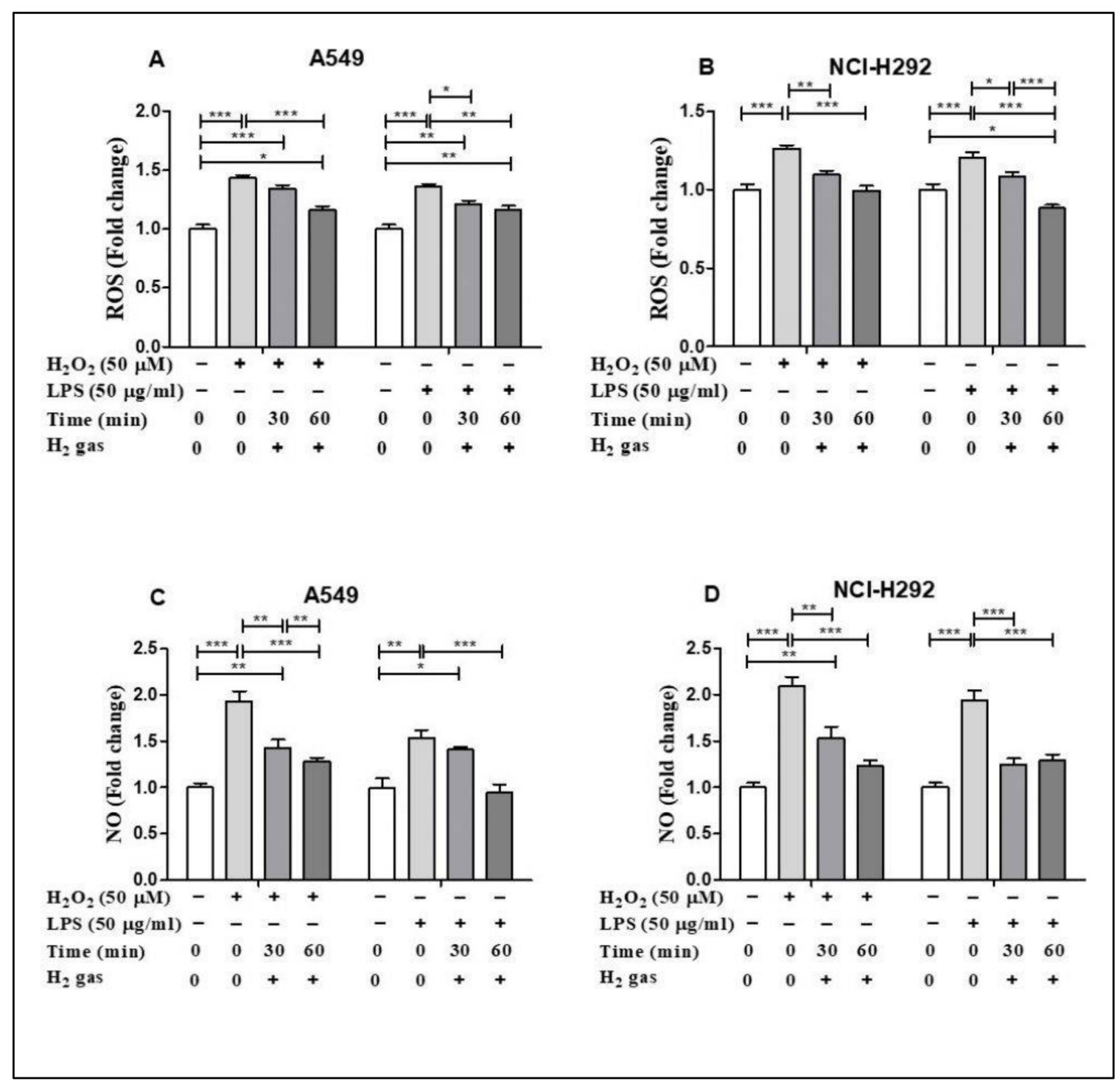

Figure 3. Effect of $2 \% \mathrm{H}_{2}$ gas on ROS and NO production in $\mathrm{H}_{2} \mathrm{O}_{2}$ and LPS-induced A549 and NCI-H292 cells. Cells were induced with $\mathrm{H}_{2} \mathrm{O}_{2}(50 \mu \mathrm{M})$ or LPS $(50 \mu \mathrm{g} / \mathrm{mL})$ for $24 \mathrm{~h}$, treated with $\mathrm{H}_{2}$ gas for $30 \mathrm{~min}$ or $60 \mathrm{~min}$, and then incubated for another $24 \mathrm{~h}$. The supernatant was collected and used to perform ROS and NO assays. (A) ROS levels in A549 cells. (B) ROS levels in NCI-H292 cells. (C) NO levels in A549 cells. (D) NO levels in NCI-H292 cells. Data are presented as mean \pm SEM. ${ }^{*} p<0.05,{ }^{* *} p<0.01$ and ${ }^{* * *} p<0.001$ represent the level of significance based on ANOVA.

\section{3. $\mathrm{H}_{2}$ Gas Has Beneficial Effect on Endogenous Antioxidant Enzyme Activities}

Of the antioxidant machineries in the cell, we selected CAT and GPx to investigate the effect of $\mathrm{H}_{2}$ gas on the activities of these enzymes under oxidative stress. In A549 cells, inducing stress using $\mathrm{H}_{2} \mathrm{O}_{2}$ and LPS significantly increased CAT activity $(p<0.001)$. This increase in CAT activity was attenuated in a time-dependent manner by an exposure to $2 \% \mathrm{H}_{2}$ gas (Figure $4 \mathrm{~A}$ ). Similarly, $\mathrm{H}_{2}$ gas treatment also significantly reduced CAT activity after $\mathrm{H}_{2} \mathrm{O}_{2}$ and LPS induction in NCI-H292 cells (Figure 4B). In contrast, the GPx assay showed a significant reduction in GPx activity after $\mathrm{H}_{2} \mathrm{O}_{2}$ and LPS induction in A549 cells $(p<0.001)$, and this was significantly rescued in a time-dependent manner after 
treatment with $\mathrm{H}_{2}$ gas (Figure 4C). Moreover, a statistically significant increase in GPx activity was observed in NCI-H292 cells after $\mathrm{H}_{2}$ gas treatment of $\mathrm{H}_{2} \mathrm{O}_{2}$ and LPS-induced cells $(p<0.001)$ (Figure 4D). These data indicate that treatment with $\mathrm{H}_{2}$ gas treatment mediates anti-oxidant enzyme activity under oxidative stress in a time-dependent manner.

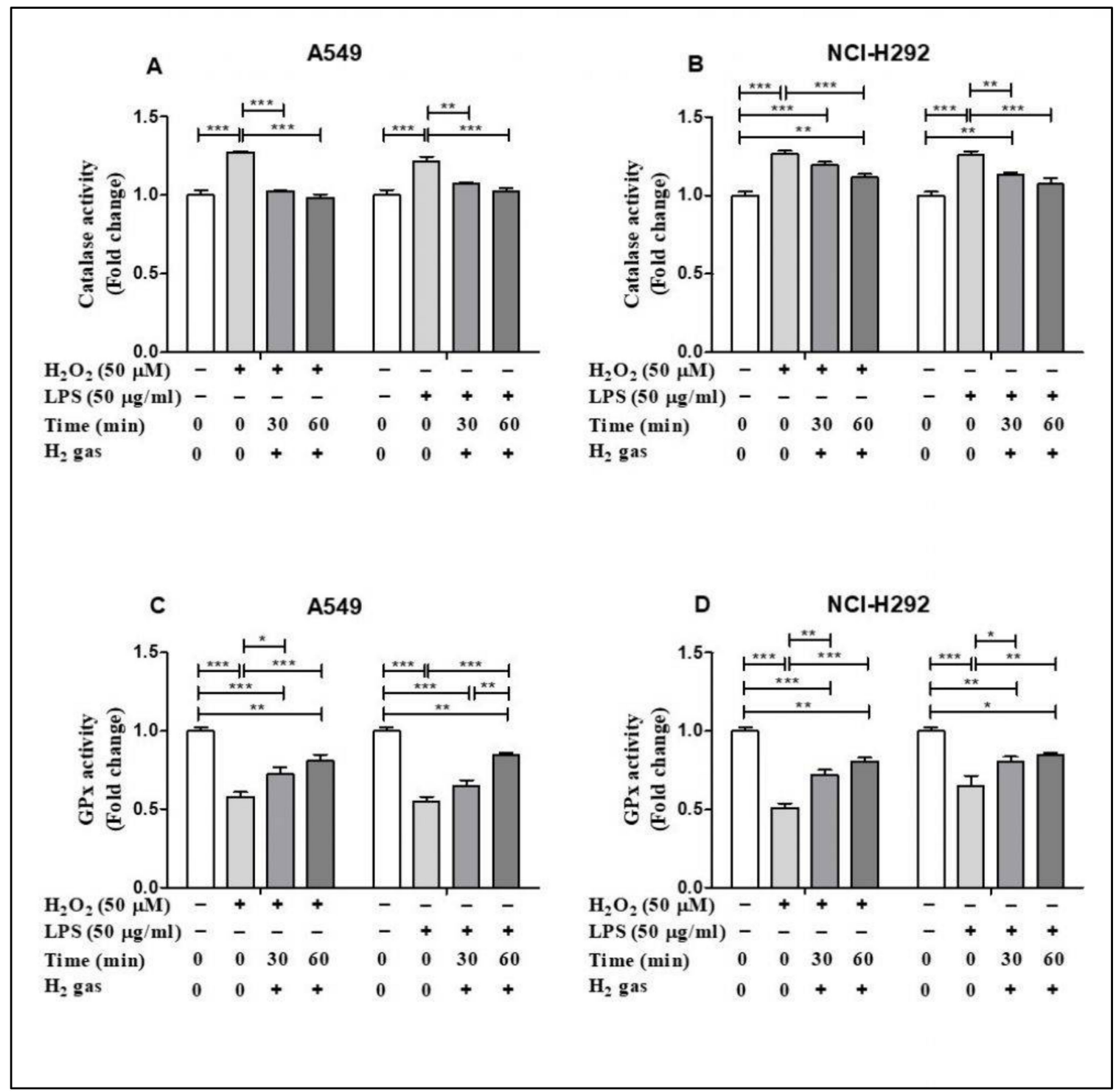

Figure 4. Influence of $2 \% \mathrm{H}_{2}$ gas on CAT and GPx activity in $\mathrm{H}_{2} \mathrm{O}_{2}$ and LPS-induced A549 and NCI-H292 cells. $\mathrm{H}_{2} \mathrm{O}_{2}$ and LPS were administered to cells at concentrations of $50 \mu \mathrm{M}$ and $50 \mu \mathrm{g} / \mathrm{mL}$, respectively. RPMI media was added and the cells incubated for $24 \mathrm{~h}$ after which they were washed and rinsed with $1 \mathrm{x}$ PBS. After $24 \mathrm{~h}$ of $\mathrm{H}_{2}$ treatment, the supernatant was isolated and CAT and GPx assay were performed. (A) CAT activity in A549 cells. (B) CAT activity in NCI-H292 cells. (C) GPx activity in A549 cells. (D) GPx activity in NCI-H292 cells. Data are presented as mean \pm SEM. Statistical significance was computed using ANOVA. ${ }^{*} p<0.05,{ }^{* *} p<0.01$ and ${ }^{* *} p<0.001$.

\subsection{Effect of $\mathrm{H}_{2}$ Gas on Quantities of Intracellular $\mathrm{Ca}^{2+}$ Concentration in $\mathrm{A} 549$ and NCI-H292 Cells}

Oxidative stress alters $\mathrm{Ca}^{2+}$ homeostasis in the cells [28]. To determine the effect of $\mathrm{H}_{2}$ gas on intracellular $\mathrm{Ca}^{2+}$ concentration, A549 and NCI-H292 cells were exposed to similar oxidative stress-inducing agents. $\mathrm{H}_{2} \mathrm{O}_{2}$ stimulation increased intracellular $\mathrm{Ca}^{2+}$ concentrations in A549 cells compared with controls $(p<0.001)$, but this effect was significantly reduced in a time-dependent manner after treatment with $\mathrm{H}_{2}$ gas (Figure $5 \mathrm{~A}$ ). Intracellular $\mathrm{Ca}^{2+}$ levels in NCI-H292 cells considerably increased after exposure to $\mathrm{H}_{2} \mathrm{O}_{2}(p<0.001)$ but reduced after treatment with $\mathrm{H}_{2}$ gas $(p<0.001)$. Furthermore, a time-dependent reduction 
in intracellular $\mathrm{Ca}^{2+}$ levels was observed $(p<0.001)$ when cells were stimulated with LPS and then treated with $\mathrm{H}_{2}$ gas (Figure 5B). These results demonstrate that intracellular $\mathrm{Ca}^{2+}$ was rescued in a time-dependent manner after treatment with $\mathrm{H}_{2}$ gas under oxidative stress.

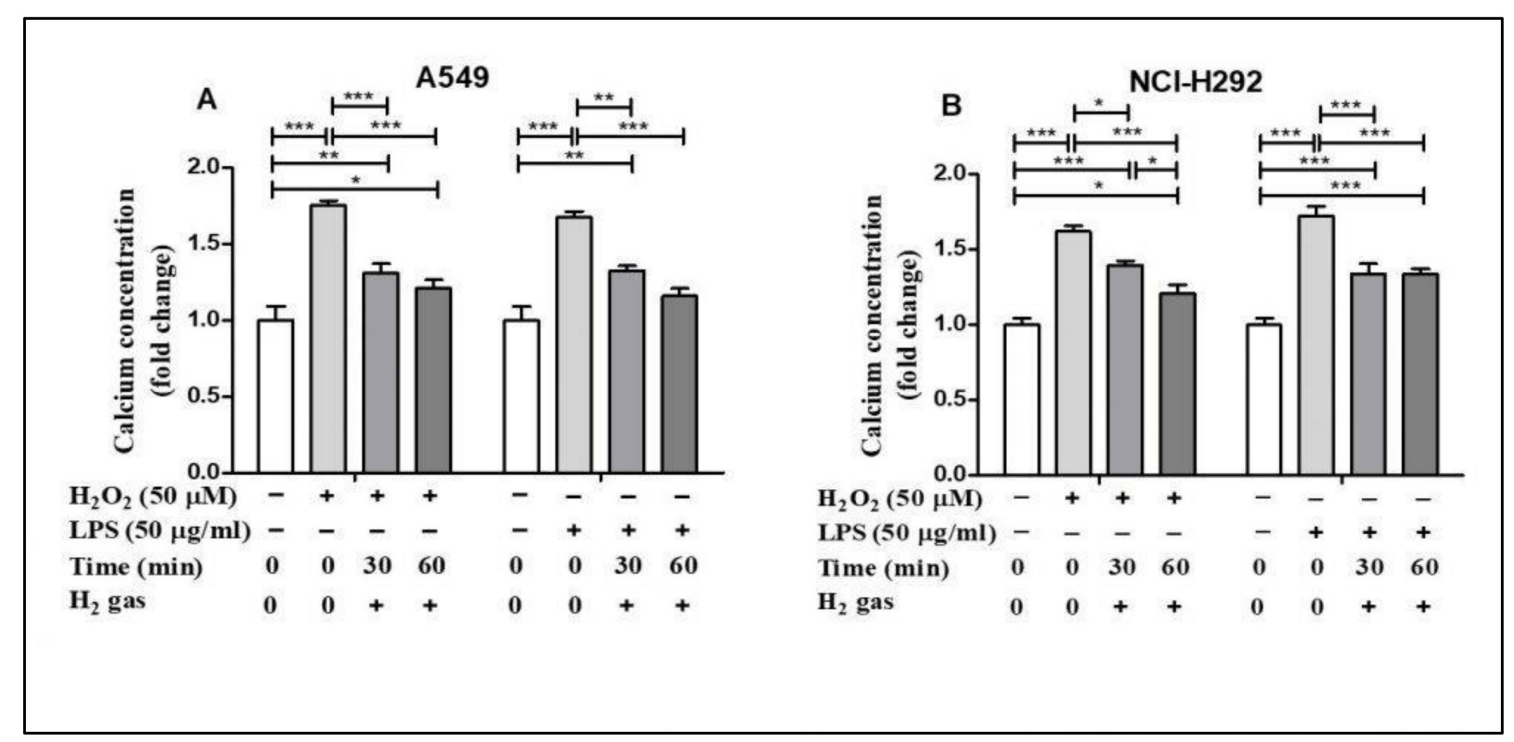

Figure 5. Effect of $2 \% \mathrm{H}_{2}$ gas on intracellular $\mathrm{Ca}^{2+}$ levels in $\mathrm{H}_{2} \mathrm{O}_{2}$ and LPS-induced A549 and NCI-H292 cells. Cells were treated with $50 \mu \mathrm{M}$ of $\mathrm{H}_{2} \mathrm{O}_{2}$ or $50 \mu \mathrm{g} / \mathrm{mL}$ of LPS and incubated for $24 \mathrm{~h}$. The cells were then washed and the media replaced with normal RPMI. The supernatant was collected after $24 \mathrm{~h}$ of $\mathrm{H}_{2}$ treatment and a $\mathrm{Ca}^{2+}$ assay was performed. $\mathrm{Ca}^{2+}$ concentrations were measured in (A) A549 cells and (B) NCI-H292 cells using one way ANOVA. ${ }^{*} p<0.05,{ }^{* *} p<0.01$, and ${ }^{* * *} p<0.001$ represent the significance levels of the results.

\subsection{Post-Treatment Effect of $\mathrm{H}_{2}$ Gas on the MAPK Pathway in A549 and NCI-H292 Cells}

To investigate the mechanism of action of $\mathrm{H}_{2}$ gas in oxidative stress, $\mathrm{p}$-JNK, $\mathrm{p}$-ERK, and p-p38 proteins in the MAPK pathway were examined. In A549 cells, the results showed that upon $\mathrm{H}_{2} \mathrm{O}_{2}$ induction, levels of the MAPK pathway proteins increased significantly compared with controls (p-JNK $(p<0.001)$, p-ERK $(p<0.01)$, and p-p38 $(p<0.001)$ ). Similarly, compared with controls, significant increase was observed in $\mathrm{p}$-JNK $(p<0.01)$, p-ERK $(p<0.01)$, and p-p38 $(p<0.05)$ in A549 cells after LPS-induction. However, the increase in MAPK pathway proteins was attenuated following 30-min or 60-min exposures to $\mathrm{H}_{2}$ gas (Figure $6 \mathrm{~A}$ ).

In NCI-H292 cells, results revealed that after $\mathrm{H}_{2} \mathrm{O}_{2}$ induction, the MAPK pathway proteins increased significantly compared with the controls (p-JNK $(p<0.01)$, p-ERK $(p<0.01)$, and p-p38 $(p<0.001))$. Similarly, compared with controls, a significant increase in p-JNK $(p<0.05)$, p-ERK $(p<0.01)$, and p-p38 $(p<0.01)$ was observed in NCI-H292 cells following induction with LPS. However, a decline in the expression of MAPK proteins in NCI-H292 cells was observed after treatment with $\mathrm{H}_{2}$ gas for specific time intervals (Figure 6B). These results demonstrate that $\mathrm{H}_{2}$ gas rescues the increase in MAPK proteins in a time-dependent manner. 


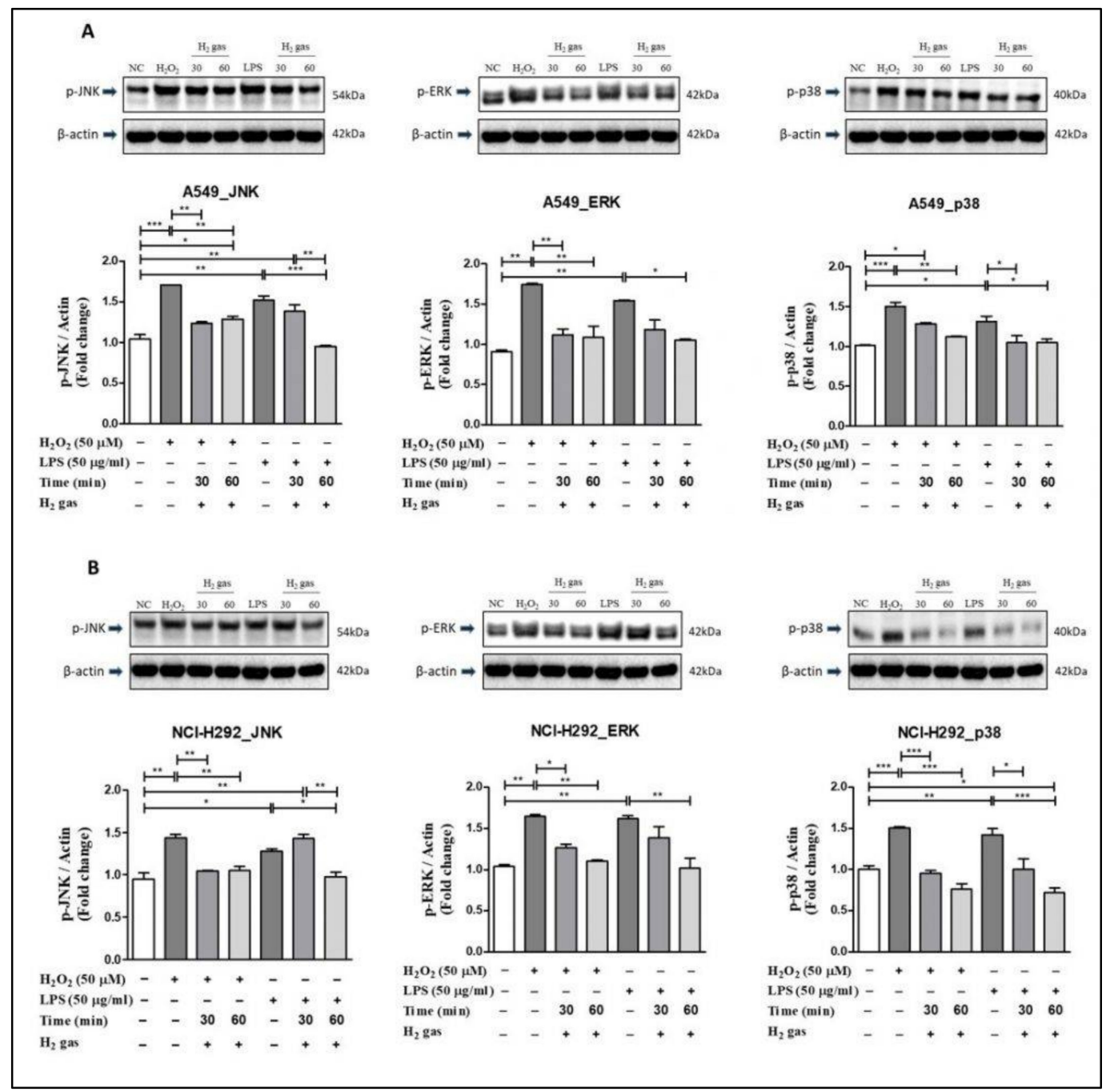

Figure 6. Effect of $2 \% \mathrm{H}_{2}$ gas on MAPK pathway proteins in cells treated with $\mathrm{H}_{2} \mathrm{O}_{2}$ and LPS. MAPK proteins p-JNK, p-ERK, and p-p38 were analyzed following $\mathrm{H}_{2}$ treatment of (A) A549 cells; and (B) NCI-H292 cells and compared with untreated controls. Image J was used to analyze the data. Data are presented as mean $\pm \mathrm{SEM}$. ${ }^{*} p<0.05$, ** $p<0.01$ and $* * * \quad p<0.001$ represent the level of significance based on ANOVA.

\section{Discussion}

This study investigated the anti-oxidative effects of $\mathrm{H}_{2}$ gas on an airway epithelial cell lines. Several studies have shown that $\mathrm{H}_{2}$ gas has beneficial effects against oxidative stress through its enhancement of antioxidant levels in different cell lines [29-33]. In addition, oxidative stress plays a role in lung injury [34-36]. The safe and effective levels for $\mathrm{H}_{2}$ gas treatment are in the $1-4 \%$ range, whereas $4-75 \%$ represent explosive levels [32]. Yu et al. reported in 2017 that by using $2 \% \mathrm{H}_{2}, v / v \%$ alleviates oxygen toxicity in PC12 cells by reducing hydroxyl radical levels. Similarly, another study conducted by Zhou et al. reported that exposing $2 \% \mathrm{H}_{2}$ gas to AR42J cells significantly reduces the inflammatory cytokines level and oxidative damage. In addition to this, the safety of using $2 \% \mathrm{H}_{2}$ has was also proved through the work of Ohta et al. [24-26]. Moreover, airway epithelial cells including A549 are alveolar cells, which prevent alveolar collapse by reducing surface tension, and NCI-H292 cells, which are located in the bronchi, act as a primary barrier for infection by secreting mucus and proteins [6,7]. Here, our study revealed the beneficial effect of $2 \% \mathrm{H}_{2}$ gas on alveolar (A549) and bronchial (NCI-H292) epithelial cells via its inhibition of MAPK signaling pathway proteins. Specifically, our research focused on the anti-oxidative effects of $2 \% \mathrm{H}_{2}$ gas on cell viability, $\mathrm{ROS}, \mathrm{NO}$, antioxidants, $\mathrm{Ca}^{2+}$, 
and MAPK signaling pathway proteins on airway epithelial cell lines at specific times and concentrations.

First, we investigated the effect of $\mathrm{H}_{2}$ gas treatment on cell viability after exposure to $\mathrm{H}_{2} \mathrm{O}_{2}$ and LPS. Several studies utilized $\mathrm{H}_{2} \mathrm{O}_{2}$ and LPS to simultaneously stimulate cellular oxidative stress and inflammation $[37,38] . \mathrm{H}_{2} \mathrm{O}_{2}$ produces $\mathrm{O}_{2}{ }^{-}$by stimulating $\mathrm{NADPH}$ oxidase whereas LPS is detected by cells and activates NADPH oxidase and nuclear factor kappa B (NF-kB), both of which cause inflammation [38,39]. As expected, we observed that induction of A549 and NCI-H292 cells using $\mathrm{H}_{2} \mathrm{O}_{2}$ and LPS reduced cell viability. However, the administration of $\mathrm{H}_{2}$ gas resulted in a substantial time-dependent increase in the viability of both cell lines. These findings support our hypothesis that treatment with $2 \%$ $\mathrm{H}_{2}$ gas reduces $\mathrm{H}_{2} \mathrm{O}_{2}$ and LPS-induced cell death in bronchial and alveolar epithelial cells.

Similarly, ROS and RNS are essential regulatory mediators of the signaling process and are important for maintaining proper cellular activity at low concentrations [19]. Increased generation of ROS and NO can result in instability of the cellular redox state and irreversible and detrimental damage to the cell, resulting in cell apoptosis [40,41]. Thus, we assessed ROS and NO production in $\mathrm{H}_{2} \mathrm{O}_{2}$ and LPS-stimulated airway epithelial cells after $\mathrm{H}_{2}$ gas treatment. We showed that $\mathrm{H}_{2}$ gas treatment inhibited the increase in ROS and NO levels caused by $\mathrm{H}_{2} \mathrm{O}_{2}$ and LPS stimulation in airway epithelial cells. We also showed that a longer duration of $\mathrm{H}_{2}$ treatment was more effective in reestablishing ROS and NO balance. $\mathrm{H}_{2}$ gas diffuses quickly over the cell membrane and reaches the cell organelles, ultimately reducing the levels of free radicals [42]. These results are supported by the studies, which found that $\mathrm{H}_{2}$ gas could inhibit the detrimental effect of ROS and free radicals generated during lung injury $[43,44]$. These findings suggest that the harmful effects of excessive production of ROS and NO in alveolar and bronchial epithelial cells can be mitigated using $\mathrm{H}_{2}$ gas.

Moreover, antioxidant enzymes such as CAT and GPx, which selectively scavenge distinct types of ROS, help in ROS detoxification. $\mathrm{H}_{2} \mathrm{O}_{2}$ is converted to water and oxygen by CAT. GPx also aids in catalyzing $\mathrm{H}_{2} \mathrm{O}_{2}$ and organic hydroperoxides [45,46]. CAT and GPx enzymes help cells get rid of free radicals [47]. Consistent with the results of these studies, our findings revealed the effect of exposure to $\mathrm{H}_{2}$ at different time intervals on boosting the activity of antioxidant enzymes such as CAT and GPx after stress induction by $\mathrm{H}_{2} \mathrm{O}_{2}$ and LPS. Furthermore, cell injury results in the loss of $\mathrm{Ca}^{2+}$ and can be reversible or irreversible depending on the level of toxicity [48]. Thus, in this experiment, we used $\mathrm{H}_{2} \mathrm{O}_{2}$ and LPS to induce cell toxicity and observed an increase in $\mathrm{Ca}^{2+}$ concentrations. This increase in $\mathrm{Ca}^{2+}$ concentration was minimized when the cells were treated with $\mathrm{H}_{2}$ gas. This result is also supported by the studies, which found that $\mathrm{H}_{2} \mathrm{O}_{2}$ increases intracellular $\mathrm{Ca}^{2+}$ overload, and $\mathrm{H}_{2}$ might regulate the levels by modifying free radicals $[49,50]$.

Finally, we focused on the MAPK signaling pathway to better understand the posttreatment mechanism of $\mathrm{H}_{2}$ gas-mediated oxidative stress. Several studies have demonstrated that MAPK proteins are essential for the conversion of extracellular signals into cell responses. The MAPK signaling pathway, which contains JNK, ERK, and p38 proteins, is one of the three primary pathways involved in cellular function. JNK and p38, commonly known as stress kinases, are activated simultaneously in response to a variety of cellular and environmental stresses, whereas ERK $1 / 2$ is activated in response to growth stimuli $[40,51-53]$. These three pathways were investigated with reference to $\mathrm{H}_{2} \mathrm{O}_{2}$ and LPS stress induction in airway epithelial cells. We observed that $\mathrm{H}_{2}$ gas reduced $\mathrm{H}_{2} \mathrm{O}_{2}$ and LPS-induced MAPK signaling pathway proteins, JNK, ERK, and p38, in a time dependent manner. These results provide evidence of the beneficial role of $\mathrm{H}_{2}$ gas in $\mathrm{H}_{2} \mathrm{O}_{2}$ and LPS-induced oxidative stress via the MAPK signaling pathway. Taken together, treatment with $\mathrm{H}_{2}$ gas rescued or restored the oxidative stress to pre-induction levels, which varied depending on the cell lines, induction method, and time for $\mathrm{H}_{2}$ gas treatment. Moreover, a 60-min $\mathrm{H}_{2}$ gas treatment was found to be more effective than a 30-min treatment in this study. 


\section{Conclusions}

In conclusion, $\mathrm{H}_{2}$ gas protected bronchial and alveolar epithelial cells against oxidative stress. Moreover, in both cell lines, exposure to $\mathrm{H}_{2}$ gas for $60 \mathrm{~min}$ was more effective than exposure for $30 \mathrm{~min}$. Oxidative stress markers and proteins in the MAPK pathway were altered after induction with $\mathrm{H}_{2} \mathrm{O}_{2}$ and LPS. These changes were alleviated by the administration of $\mathrm{H}_{2}$ gas. The findings provide an effective way for reducing oxidative stress-induced injury in bronchial and alveolar epithelial cells. However, further studies are needed to fully elucidate the molecular mechanisms underlying $\mathrm{H}_{2}$ function in vivo and clinical studies. However, to our knowledge, this is the first report that shows the antioxidant effect of $\mathrm{H}_{2}$ in both bronchial and alveolar epithelial cells in $\mathrm{H}_{2} \mathrm{O}_{2}$ and LPS-induced oxidative stress.

Supplementary Materials: The following are available online, Figure S1: Analysis of IC50 at different time and concentration. (A) $\mathrm{H}_{2} \mathrm{O}_{2}$ induction in A549 cells; (B) LPS induction in A549 cells; (C) $\mathrm{H}_{2} \mathrm{O}_{2}$ induction in NCI-H292 cells; (D) LPS induction in NCI-H292 cells.

Author Contributions: Conceptualization, I.-S.Y. and S.S.; review and editing, C.-S.K., A.F. and J.B.; Supervision, K.-J.L.; investigation, S.S., I.-S.Y., T.T.T., M.H.R., J.S., H.-U.K. and S.-Y.L.; writingoriginal draft preparation, I.S.Y. and S.S. All authors have read and agreed to the published version of the manuscript.

Funding: This research was funded by GOOTZ Co., Ltd., Gyeonggi-do, Republic of Korea, grant number 2021-51-0016.

Institutional Review Board Statement: Not applicable.

Informed Consent Statement: Not applicable.

Data Availability Statement: All the data are contained within the article.

Conflicts of Interest: The authors declare no conflict of interest.

Sample Availability: Samples of the compounds are not available from the authors.

\begin{tabular}{ll}
\multicolumn{2}{l}{ Abbreviations } \\
& \\
ROS & Reactive oxygen species \\
$\mathrm{H}_{2} \mathrm{O}_{2}$ & Hydrogen peroxide \\
$\mathrm{LPS}^{2+}$ & Lipopolysaccharide \\
$\mathrm{Ca}^{2+}$ & Calcium \\
$\mathrm{RNS}$ & Reactive nitrogen species \\
$\mathrm{NO}$ & Nitric oxide \\
$\mathrm{ONOO}-$ & Peroxynitrite \\
$\mathrm{GPx}$ & Glutathione peroxidase \\
$\mathrm{CAT}$ & Catalase \\
$\mathrm{MAPK}$ & Mitogen activated protein kinase \\
$\mathrm{JNK}$ & C-Jun N-terminal kinase \\
ERK & Extracellular signal regulated kinases \\
$\mathrm{H} 2$ & Molecular hydrogen \\
•OH & Hydroxyl radical \\
RPMI & Roswell park memorial institute \\
FBS & Fetal bovine serum \\
$\mathrm{CO}$ & Carbon dioxide \\
Ind & Induction \\
$\mathrm{CCK}-8$ & Cell counting kit- 8 \\
SDS-PAGE & Sodium dodecyl sulfate-polyacrylamide gel electrophoresis \\
SEM & Standard error of the mean \\
ANOVA & Analysis of variance \\
NF- $\mathrm{KB}$ & Nuclear factor kappa B
\end{tabular}




\section{References}

1. Schünemann, H.J.; Muti, P.; Freudenheim, J.L.; Armstrong, D.; Browne, R.; Klocke, R.A.; Trevisan, M. Oxidative stress and lung function. Am. J. Epidemiol. 1997, 146, 939-948. [CrossRef]

2. Reuter, S.; Gupta, S.C.; Chaturvedi, M.M.; Aggarwal, B.B. Oxidative stress, inflammation, and cancer: How are they linked? Free Radic. Biol. Med. 2010, 49, 1603-1616. [CrossRef] [PubMed]

3. Shi, X.; Ding, M.; Chen, F.; Wang, J.-C.; Rojanasakul, Y.; Vallyathan, V. Reactive oxygen species and molecular mechanism of silica-induced lung injury. J. Environ. Pathol. Toxicol. Oncol. 2001, 20 (Suppl. 1), 85-93. [CrossRef] [PubMed]

4. Cantin, A.; North, S.; Fells, G.; Hubbard, R.; Crystal, R. Oxidant-mediated epithelial cell injury in idiopathic pulmonary fibrosis. J. Clin. Invest. 1987, 79, 1665-1673. [CrossRef]

5. Kinnula, V.L.; Crapo, J.D. Superoxide dismutases in the lung and human lung diseases. Am. J. Respir. Crit. Care Med. 2003, 167, 1600-1619. [CrossRef]

6. Dezfouli, M.R.M.; Chaleshtori, S.S.; Baharvand, H.; Tahamtani, Y.; Yadollahi, S. P233-effects of A549-condition medium on mouse embryonic stem cells differentiation into alveolar epithelial type II cells. In Proceedings of the International Congress on Stem Cells and Regenerative Medicine, Antalya, Turkey, 15-18 October 2015. Available online: https://www.sid.ir/En/Seminar/ ViewPaper.aspx?ID=21184.

7. Sanchez-Guzman, D.; Boland, S.; Brookes, O.; Mc Cord, C.; Kuen, R.L.; Sirri, V.; Squiban, A.B.; Devineau, S. Long-term evolution of the epithelial cell secretome in preclinical 3D models of the human bronchial epithelium. Sci. Rep. 2021, 11, 1-14.

8. Vilema-Enríquez, G.; Arroyo, A.; Grijalva, M.; Amador-Zafra, R.I.; Camacho, J. Molecular and cellular effects of hydrogen peroxide on human lung cancer cells: Potential therapeutic implications. Oxid. Med. Cell. Longev. 2016, 2016, 1908164. [CrossRef]

9. Chuang, C.-Y.; Chen, T.-L.; Cherng, Y.-G.; Tai, Y.-T.; Chen, T.-G.; Chen, R.-M. Lipopolysaccharide induces apoptotic insults to human alveolar epithelial A549 cells through reactive oxygen species-mediated activation of an intrinsic mitochondriondependent pathway. Arch. Toxicol. 2011, 85, 209-218. [CrossRef]

10. Chen, Y.-W.; Yang, Y.-T.; Hung, D.-Z.; Su, C.-C.; Chen, K.-L. Paraquat induces lung alveolar epithelial cell apoptosis via Nrf-2-regulated mitochondrial dysfunction and ER stress. Arch. Toxicol. 2012, 86, 1547-1558. [CrossRef]

11. Pizzino, G.; Irrera, N.; Cucinotta, M.; Pallio, G.; Mannino, F.; Arcoraci, V. Oxidative stress: Harms and benefits for human health. Oxid. Med. Cell. Longev. 2017, 2017, 8416763. [CrossRef] [PubMed]

12. Zorov, D.B.; Juhaszova, M.; Sollott, S.J. Mitochondrial reactive oxygen species (ROS) and ROS-induced ROS release. Physiol. Rev. 2014, 94, 909-950. [CrossRef]

13. Di Meo, S.; Reed, T.T.; Venditti, P.; Victor, V.M. Role of ROS and RNS sources in physiological and pathological conditions. Oxid. Med. Cell. Longev. 2016, 2016, 1245049. [CrossRef] [PubMed]

14. Ighodaro, O.M.; Akinloye, O.A. First line defence antioxidants-superoxide dismutase (SOD), catalase (CAT) and glutathione peroxidase (GPX): Their fundamental role in the entire antioxidant defence grid. Alexandria J. Med. 2018, 54, 287-293. [CrossRef]

15. Ku, B.M.; Lee, Y.K.; Jeong, J.Y.; Mun, J.; Han, J.Y.; Roh, G.S. Ethanol-induced oxidative stress is mediated by p38 MAPK pathway in mouse hippocampal cells. Neurosci. Lett. 2007, 419, 64-67. [CrossRef] [PubMed]

16. Huang, C.-S.; Kawamura, T.; Toyoda, Y.; Nakao, A. Recent advances in hydrogen research as a therapeutic medical gas. Free Radic. Res. 2010, 44, 971-982. [CrossRef]

17. Ohta, S. Molecular hydrogen is a novel antioxidant to efficiently reduce oxidative stress with potential for the improvement of mitochondrial diseases. Biochim. Biophys. Acta Gen. Subj. 2012, 1820, 586-594. [CrossRef] [PubMed]

18. Kyriakis, J.M.; Avruch, J. Mammalian mitogen-activated protein kinase signal transduction pathways activated by stress and inflammation. Physiol. Rev. 2001, 81, 807-869. [CrossRef]

19. Gharib, B.; Hanna, S.; Abdallahi, O.M.; Lepidi, H.; Gardette, B.; De Reggi, M. Anti-inflammatory properties of molecular hydrogen: Investigation on parasite-induced liver inflammation. Compt. Rendus. Acad. Sci. III Sci. Vie 2001, 324, 719-724. [CrossRef]

20. Xie, K.; Yu, Y.; Pei, Y.; Hou, L.; Chen, S.; Xiong, L. Protective effects of hydrogen gas on murine polymicrobial sepsis via reducing oxidative stress and HMGB1 release. Shock 2010, 34, 90-97. [CrossRef]

21. Itoh, T.; Hamada, N.; Terazawa, R.; Ito, M.; Ohno, K.; Ichihara, M. Molecular hydrogen inhibits lipopolysaccharide/interferon $\gamma$-induced nitric oxide production through modulation of signal transduction in macrophages. Biochem. Biophys. Res. Commun. 2011, 411, 143-149. [CrossRef] [PubMed]

22. Qian, L.; Cao, F.; Cui, J.; Huang, Y.; Zhou, X.; Liu, S. Radioprotective effect of hydrogen in cultured cells and mice. Free Radic. Res. 2010, 44, 275-282. [CrossRef]

23. Begum, R.; Kim, C.S.; Fadriquela, A.; Bajgai, J.; Jing, X.; Kim, D.H.; Kim, S.K.; Lee, K.J. Molecular hydrogen protects against oxidative stress-induced RAW 264.7 macrophage cells through the activation of Nrf2 and inhibition of MAPK signaling pathway. Mol. Cell. Toxicol. 2020, 16, 103-118.

24. Yu, J.; Yu, Q.; Liu, Y.; Zhang, R.; Xue, L. Hydrogen gas alleviates oxygen toxicity by reducing hydroxyl radical levels in PC12 cells. PLoS ONE 2017, 12, e0173645. [CrossRef]

25. Zhang, C.B.; Tang, Y.C.; Xu, X.J.; Guo, S.X.; Wang, H.Z. Hydrogen gas inhalation protects against liver ischemia/reperfusion injury by activating the NF- $\kappa B$ signaling pathway. Exp. Ther. Med. 2015, 9, 2114-2120. [CrossRef] [PubMed]

26. Zhou, H.X.; Han, B.; Hou, L.M.; An, T.T.; Jia, G.; Cheng, Z.X.; Ma, Y.; Zhou, Y.N.; Kong, R.; Wang, S.J.; et al. Protective effects of hydrogen gas on experimental acute pancreatitis. PLoS ONE 2016, 11, e0154483. [CrossRef] [PubMed] 
27. Kurokawa, R.; Seo, T.; Sato, B.; Hirano, S.I.; Sato, F. Convenient methods for ingestion of molecular hydrogen: Drinking, injection, and inhalation. Med. Gas Res. 2015, 5, 1-8. [CrossRef]

28. Persson-Rothert, M.; Egas-Kenniphaas, J.; Van der Valk-Kokshoorn, E.; Buys, J.; Van Der Laarse, A. Oxidative stress-induced perturbations of calcium homeostasis and cell death in cultured myocytes: Role of extracellular calcium. Mol. Cell. Biochem. 1994, 136, 1-9. [CrossRef] [PubMed]

29. Ohta, S. Recent progress toward hydrogen medicine: Potential of molecular hydrogen for preventive and therapeutic applications. Curr. Pharm. Des. 2011, 17, 2241-2252. [CrossRef] [PubMed]

30. Rahman, M.; Bajgai, J.; Fadriquela, A.; Sharma, S.; Trinh Thi, T.; Akter, R. Redox Effects of Molecular Hydrogen and Its Therapeutic Efficacy in the Treatment of Neurodegenerative Diseases. Processes 2021, 9, 308. [CrossRef]

31. Yang, Y.; Zhu, Y.; Xi, X. Anti-inflammatory and antitumor action of hydrogen via reactive oxygen species. Oncol. Lett. 2018, $16,2771-2776$.

32. Ohta, S. Molecular hydrogen as a preventive and therapeutic medical gas: Initiation, development and potential of hydrogen medicine. Pharmacol. Ther. 2014, 144, 1-11. [CrossRef]

33. Wang, D.; Wang, L.; Zhang, Y.; Zhao, Y.; Chen, G. Hydrogen gas inhibits lung cancer progression through targeting SMC3. Biomed. Pharmacother. 2018, 104, 788-797. [CrossRef] [PubMed]

34. Kratzer, E.; Tian, Y.; Sarich, N.; Wu, T.; Meliton, A.; Leff, A. Oxidative stress contributes to lung injury and barrier dysfunction via microtubule destabilization. Am. J. Respir. Cell Mol. Biol. 2012, 47, 688-697. [CrossRef] [PubMed]

35. Dong, Z.; Yuan, Y. Accelerated inflammation and oxidative stress induced by LPS in acute lung injury: Inhibition by ST1926. Int. J. Mol. Med. 2018, 41, 3405-3421. [CrossRef]

36. Valavanidis, A.; Vlachogianni, T.; Fiotakis, K.; Loridas, S. Pulmonary oxidative stress, inflammation and cancer: Respirable particulate matter, fibrous dusts and ozone as major causes of lung carcinogenesis through reactive oxygen species mechanisms. Int. J. Environ. Res. Public Health 2013, 10, 3886-3907. [CrossRef] [PubMed]

37. Ransy, C.; Vaz, C.; Lombès, A.; Bouillaud, F. Use of $\mathrm{H}_{2} \mathrm{O}_{2}$ to cause oxidative stress, the catalase issue. Int. J. Mol. Sci. 2020, 21, 9149. [CrossRef]

38. Yücel, G.; Zhao, Z.; El-Battrawy, I.; Lan, H.; Lang, S.; Li, X. Lipopolysaccharides induced inflammatory responses and electrophysiological dysfunctions in human-induced pluripotent stem cell derived cardiomyocytes. Sci. Rep. 2017, 7, 1-13. [CrossRef]

39. Dupuy, C.; Virion, A.; Ohayon, R.; Kaniewski, J.; Deme, D.; Pommier, J. Mechanism of hydrogen peroxide formation catalyzed by NADPH oxidase in thyroid plasma membrane. J. Biol. Chem. 1991, 266, 3739-3743. [CrossRef]

40. Wang, M.; Cao, X.; Luan, C.; Li, Z. Hydrogen sulfide attenuates hydrogen peroxide-induced injury in human lung Epithelial A549 cells. Int. J. Mol. Sci. 2019, 20, 3975. [CrossRef]

41. Lubos, E.; Handy, D.E.; Loscalzo, J. Role of oxidative stress and nitric oxide in atherothrombosis. Front. Biosci. 2008, $13,5323$. [CrossRef]

42. Murakami, Y.; Ito, M.; Ohsawa, I. Molecular hydrogen protects against oxidative stress-induced SH-SY5Y neuroblastoma cell death through the process of mitohormesis. PLoS ONE 2017, 12, e0176992. [CrossRef]

43. LeBaron, T.W.; Kura, B.; Kalocayova, B.; Tribulova, N.; Slezak, J. A new approach for the prevention and treatment of cardiovascular disorders. Molecular hydrogen significantly reduces the effects of oxidative stress. Molecules 2019, 24, 2076. [CrossRef] [PubMed]

44. Kokubo, K.; Inoue, T.; Yamashita, K.; Shinbo, T.; Hirose, M.; Kobayashi, H. Hydrogen gas alters the production of reactive oxygen species in alveolar epithelial cells in vitro. Eur. Respir. J. 2012, 40 (Suppl. 56), 3379.

45. Liou, G.-Y.; Storz, P. Reactive oxygen species in cancer. Free Radic. Res. 2010, 44, 479-496. [CrossRef]

46. Heck, D.E.; Shakarjian, M.; Kim, H.D.; Laskin, J.D.; Vetrano, A.M. Mechanisms of oxidant generation by catalase. Ann. N. Y. Acad. Sci. 2010, 1203, 120. [CrossRef]

47. Jeon, G.; Kim, C.; Cho, U.M.; Hwang, E.T.; Hwang, H.S.; Min, J. Melanin-decolorizing activity of antioxidant enzymes, glutathione peroxidase, thiol peroxidase, and catalase. Mol. Biotechnol. 2021, 63, 150-155. [CrossRef] [PubMed]

48. Dong, Z.; Saikumar, P.; Weinberg, J.M.; Venkatachalam, M.A. Calcium in cell injury and death. Annu. Rev. Pathol. Mech. Dis. 2006, 1, 405-434. [CrossRef]

49. Herson, P.S.; Lee, K.; Pinnock, R.D.; Hughes, J.; Ashford, M.L. Hydrogen peroxide induces intracellular calcium overload by activation of a non-selective cation channel in an insulin-secreting cell line. J. Biol. Chem. 1999, 274, 833-841. [CrossRef] [PubMed]

50. Iuchi, K.; Imoto, A.; Kamimura, N.; Nishimaki, K.; Ichimiya, H.; Yokota, T. Molecular hydrogen regulates gene expression by modifying the free radical chain reaction-dependent generation of oxidized phospholipid mediators. Sci. Rep. 2016, 6, 1-12. [CrossRef]

51. Zhang, W.; Liu, H.T. MAPK signal pathways in the regulation of cell proliferation in mammalian cells. Cell Res. 2002, 12, 9-18. [CrossRef]

52. Wang, W.; Zheng, J.-P.; Zhu, S.-X.; Guan, W.-J.; Chen, M.; Zhong, N.-S. Carbocisteine attenuates hydrogen peroxide-induced inflammatory injury in A549 cells via NF-kB and ERK1/2 MAPK pathways. Int. Immunopharmacol. 2015, 24, 306-313. [CrossRef]

53. Wada, T.; Penninger, J.M. Mitogen-activated protein kinases in apoptosis regulation. Oncogene 2004, 23, 2838-2849. [CrossRef] [PubMed] 